\title{
16
}

\section{Melodrama, celebrity, The Queen}

\author{
Mandy Merck
}

In 1955 the New Statesman published an article by the pundit Malcolm Muggeridge with a headline that would become a cliché of British political commentary. Republished in May 2012 for the Queen's Diamond Jubilee, 'The Royal Soap Opera' compared newspaper coverage of Princess Margaret's romance with Royal Air Force Group Captain Peter Townsend to that bestowed on Rita Hayworth. 'The application of film-star techniques to representatives of a monarchical institution is liable to have', it warned, 'disastrous consequences':

The film star soon passes into oblivion. She has her moment and then it is all over. And even her moment depends on being able to do superlatively well whatever the public expects of her. Members of the royal family are in an entirely different situation. Their role is to symbolize the unity of a nation; to provide an element of continuity in a necessarily changing society. This is history, not The Archers, ${ }^{1}$ and their affairs ought to be treated as such. ${ }^{2}$

Thirty years passed before Judith Williamson challenged Muggeridge by claiming that this celebrity melodrama could actually serve the Crown and the ideology of national unity that it represents. Writing just after the protracted strike that failed to halt the closure of Britain's coal mines in 1984, Williamson observed that the pitmen's wives sought the Queen's support for their cause in the belief that she cared, that the ambiguous 'concern' about the strike expressed in a palace press release indicated a royal regard for ordinary Britons' welfare not shared by the elected government of Conservative Prime Minister Margaret Thatcher. That belief, Williamson argued, has been bolstered by the British monarchy's cultivation of a middle-class domestic image since the reign of Victoria. In 'incorporating both affection (based on identification) and obedience (based on difference)', it has employed a canny populism to foster both: 'There is the 
intimate and casual private moment on the one hand; the spectacle of State occasions, the glamour of wealth and national tradition on the other. ${ }^{33}$ Royal privilege and ceremonial display have increasingly been combined with publicity focused on the ordinary interests of romance, marriage, children and the home the basic materials of melodrama - with considerable political success. And thus, when Muggeridge's 'orgy of vulgar and sentimental speculation' about whether Princess Margaret would renounce her title to marry a divorced man was echoed half a century later by similar speculation about whether her nephew would marry a divorced woman, both romance and royal status, desire and duty, were upheld. Prince Charles married Camilla Parker Bowles, the former wife of a Commander of the Household Cavalry, in 2005, the year before the release of an actual melodrama with a real-life film star commemorating (and, by many accounts, furthering) the Crown's survival of its greatest modern crisis.

Discussing the melodramatic concentration on 'family relationships, star-crossed lovers and forced marriages' in the direct predecessor of the genre, the eighteenth-century bourgeois tragedy, Thomas Elsaesser discerns a strong anti-feudalism in its portrayal of the villains. 'Often of noble birth', they 'demonstrate their superior political and economic power invariably by sexual aggression. ${ }^{34}$ Although that storyline would serve very well for the 1997 contretemps provoked by the British royal family's cynical betrothal of the heir to the throne to a naive teenager, The Queen's restaging of these conflicts in the domestic life of the Windsors makes the monarch the heroine, albeit a monarch portrayed as a beleaguered working woman in the Hollywood melodramatic mode, with even more pathos given her advanced age: the concerned Chief Executive of the royal 'firm,' torn in the crisis after Diana's death between her lifelong reserve and her anointed obligations to her symbolically childish subjects. This transfer of spectatorial sympathy represents a political coup de théatre, and has been acknowledged as such. Not untypically, royal biographer William Shawcross maintains that The Queen rebutted allegations of the monarch's 'uncaring' attitude to Diana's death, capturing its subject's 'moral courage' and eliciting many letters from members of the public 'saying that before the film they had never quite understood what she had been through, others saying how glad they were that the film had finally tried to tell the truth they had always accepted'. ${ }^{5}$ As film critic David Thomson succinctly concludes, the film is 'the most sophisticated public relations boost HRH had had in 20 years' . ${ }^{6}$

Princess Diana would seem the more likely heroine of this melodrama, the beautiful young innocent deceived by a powerful older man. Thwarted in love, 
spurned by her husband's family, harried by the press, she became a figure of female suffering and resistance, pointing the finger of accusation à la Lillian Gish in the 1995 BBC Panorama interview viewed by the Queen in the film: 'There were three of us in this marriage.' The cinematic character of Diana's celebrity was redoubled by the sense that this shy young woman had been 'discovered"7 by her husband, painfully wrenched from private life to mass exposure and early death like the doomed Norma Jean whose ballad was rewritten for her funeral. As journalist Allan Massie argues, Diana, although the daughter of an earl, was 'unquestionably' the star of 'the Royal soap opera' and the 'child of her age':

Not long after Diana's death, Tony Blair, as prime minister, called for the release of Deidre Rachid, a fictional character fictionally imprisoned for a fictional offence in Coronation Street. ${ }^{8}$ Many mocked his intervention, but in this confusion of real life and television, he represented the spirit of the times.... When Diana was killed, and Blair pronounced her 'the People's Princess', it was hard to remember that she was actually a member of one of the great Whig aristocratic families. The image, only partly manufactured, had all but obliterated the reality.

But if The Queen is a melodrama attempting to replace this generic heroine with the living monarch, it was initially devised as a docudrama, with that form's fidelity to actual events and the employment of both television and press quotation. Real and simulated footage from British newscasts is interspersed with a fictional narrative of both the royal family and the Labour government's response to Diana's death. Written by Peter Morgan, The Queen is the centrepiece of his New Labour trilogy in which Michael Sheen plays Tony Blair, and it was also destined for the small screen before continental co-production expanded its budget. The two television productions which bracket it are The Deal (directed by Stephen Frears, 2003) on the power-sharing negotiations between Tony Blair and Gordon Brown prior to their government's first election, and The Special Relationship (directed by Richard Loncraine, 2009) on Blair's dealings with US presidents Clinton and Bush.

In many ways The Queen follows the formula of The Deal as closely as its two-syllable title. Both were directed by Stephen Frears and both focus on real-life political contests in which a frontrunner is defeated by a rival. Real-life Labour spin doctors (Peter Mandelson, played by Paul Rhys in The Deal, and Alastair Campbell, played by Mark Bazely in The Queen) take key supportive roles. Footage of an actual funeral appears at the climax of both narratives and 
both end with an ironic coda. The difference between the two productions is significantly that of their medium, which 'opens out' The Queen to the production values of the feature film, while confining The Deal to the cheaper mise-en-scène of television. In the latter there is consequently little visible difference between the low-resolution image of its dramatic sequences and that of the video news archive. Although The Deal does employ scenes of people watching television to bridge the two, it also cuts directly between them with no ostensible breach of image quality or narrative continuity. ${ }^{10}$ Significantly the deceased politician in the archive sequence of the funeral, the Scottish Labour leader John Smith, is portrayed earlier by actor Frank Kelly. Conversely Diana - even in the opening of The Queen when she is still alive - is represented only by actuality footage. Belén Vidal has called attention to the 'different temporalities"11 signalled by the film's textual - and textural - variation, observing both its insertion of Mirren's enacted Queen into the documentary record and the Crown into a belated engagement with twentieth-century communications. But this division has a further import, one of character, genre and ontology, since the Queen is entirely portrayed by an actor and seen mostly in the fictional melodrama filmed by Frears, while Diana is confined to the archive of her indexical image. While avoiding what Giselle Bastin has described as the 'low-quality' impersonations of the Princess in the many television biopics of the 1980 s and $1990 \mathrm{~s}^{12}$ this strategy makes Diana history, in both the literal and figurative sense, while paradoxically enlivening the very traditional genre which it deploys to vindicate the Queen.

Throughout The Queen news broadcasts on television screens and photographic images are counterposed to the paintings in the royal residences and Downing Street. Their thematic purposes are multifold, but they mark a dramatic progress in which Diana - effectively portrayed as pretender to the throne - is supplanted in the televisual frame by the Queen, who is initially identified with the milieu and iconography of fine art. Only when this process has been completed can Diana's funeral begin and the Princess be laid to rest, and with her the threat she presents to the Queen's authority. To make this happen, melodrama, with its pathos, its appeal for moral recognition and its highly expressive mise-en-scène, must, in both a political and an aesthetic sense, dominate the docudrama. The DVD cover of The Queen announces this generic contest with an eloquent image absent from the actual film. In it Helen Mirrencostumed for the title role in funereal black, with discreet pearls at her neck and a white rose brooch - stands frowning in front of a gigantic photograph of the 


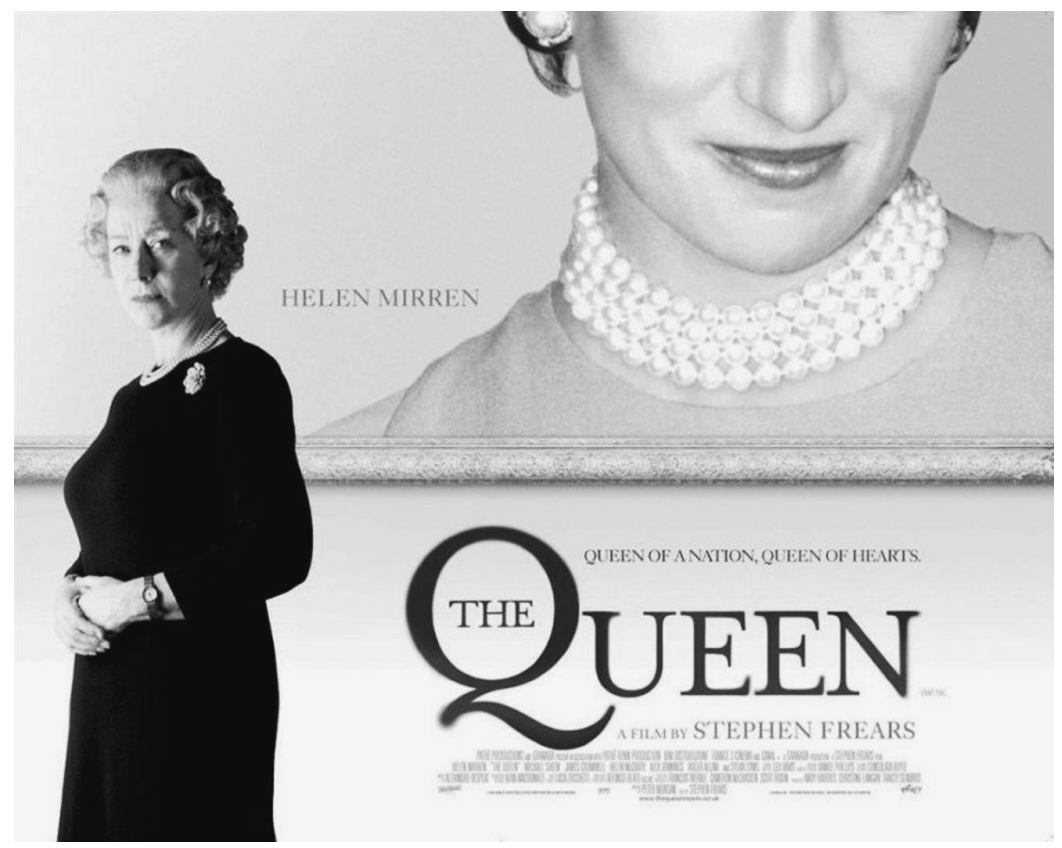

32 'Queen of a Nation, Queen of Hearts': the DVD cover image for The Queen (Stephen Frears, 2006).

real-life Diana. In a markedly competitive pose, Mirren's Queen has turned her back to the photograph. It is cropped just below Diana's eyes, masking her gaze at the spectator, but emphasising its subject's smile, as well as her more youthful complexion. Yet the photograph is toned a ghostly grey, while the figure in the foreground is in colour. A caption reads (in conservative blue) QUEEN OF A NATION, (and in radical red) QUEEN OF HEARTS.

Stephen Heath's term 'narrative image ${ }^{13}$ suggests how this illustration anticipates the film's abiding contrast of photographic publicity with private existence. For much of its running time, the nation's Queen is out of the public eye, at Balmoral, her Scottish hunting estate. Meanwhile, the Queen of hearts is montaged in the cascade of images with which her life culminated, watched repeatedly on television, pursued to her death by the paparazzi and memorialised by her photographs on thousands of mourners' placards. The medial frame, it is suggested, has been usurped by the Queen's rival, her former daughter-in-law. In the tradition of Friedrich Schiller's 1800 play Mary Stuart (whose sympathetic treatment of both Mary of Scotland and Elizabeth I makes 
it a more obvious precedent for this melodrama than the royal villain plays cited by Elsaesser), this is a drama about two ambitious queens, one romantic, one worldly, in a contest for power. Although Diana's death is announced soon after the film begins, her threat to the Crown cannot be averted until the anointed monarch reoccupies her rightful place within the frame and broadcasts a statement of regret to the nation. And even then the ghostly pretender lingers on, her archive image twice inserted into that of the mourners at her own funeral, the second time in a confrontational turn toward the camera that matches the Queen's at the film's opening.

Both Vidal and Bastin have rightly stressed this spectrality. Diana's representations throughout the film are figured as both posthumous (at its 2006 debut she had been dead for nine years and she dies again at its beginning) and ghostlike, reconfigured in (mostly) silence, slow motion and the lower resolution and desaturated colours of television news. These enhance the haunting effect of her image in the present absence so often remarked upon by theorists of photography. Throughout the film this documentary footage of the dead Princess is watched by the film's characters, played by actors filmed in the higher resolution, deeper hues and synchronised sound of the feature film. Thus we are given two realities in two different registrations - that of the fictional world of melodrama and that of the actual world of documentary. But here, enhanced by cinema's larger gauge, lighting, set design, casting and sheer scale (in both financial and figural terms), the symbolic world of the melodrama is more vivid, more audible and apparently more alive than the indexical images of the real-life Diana. The Queen of Hearts is dead. Long live the Queen of a Nation (who will become, through the sympathetic agency of the melodrama, the next Queen of Hearts).

As well as the images framed by the television screen, gilt-framed paintings adorn the more formal settings of this film. Like the harpsichord passage that introduces the Palace in the scene in which the newly elected Blair is confirmed Prime Minister, these works of art synedochise the aesthetics of tradition, wealth and offices of state. The conflict between the two media is introduced in its title scene, when the Queen watches the news as she poses in the ceremonial robes of the chivalric Order of the Garter for an artist in a Buckingham Palace state room. ${ }^{14}$ It is Election Day, 1997, and the first shot of the film is a televised one of a contemporary Labour Party supporter, as indicated by the 'Britain deserves better' slogan on his red T-shirt. Yet the era of Muggeridge's article persists, since the Queen's pose and costume are designed to recall her most 
famous portrait, painted by Pietro Annigoni in 1954-55, when she was in her late 20s. The grey hair and West Indian accent of the film's fictional painter, $\mathrm{Mr}$ Crawford, also recall the bygone heyday of immigration from the Caribbean. Moreover, the character is portrayed by Earl Cameron, best known for the 1950s and 60 s film and television melodramas in which he so often played the virtuous victim of racist violence (Sapphire, Basil Deardon, 1959) or exploitation (Flame in the Streets, Roy Ward Baker, 1961). The name Crawford is itself an allusion to 1950, the year when the former nanny of Elizabeth and Margaret, Marion Crawford or 'Crawfie', outraged the royal family by publishing her memoir The Little Princesses. But the ease with which Mr Crawford converses with his sovereign also suggests the ethnic 'diversity' championed in the Blair era. Combined with the casting of Mirren (playing the then seventy-one-year-old monarch at the age of sixty-one) the effect is to make the Queen both venerable and youthful - a veteran of ten prime ministers as she will later remind Blair - and yet in her pose for this portrait strikingly elegant, a star.

In the narrative device that structures the entire film, the situation of the title scene is announced by the television. As the painter works, the news in the background is of Tony Blair's arrival, aged forty-three, to cast his vote at his constituency's polling station. This provokes an amiable discussion in which the presumptive hierarchies of race, gender, politics and portraiture are put into question. Playing on the role of the Queen as the artist's subject, and the artist as subject of the Queen (Britons are not citizens but 'subjects' of the Crown), the scene manoeuvres them into equilibrium. As sovereign, the Queen points out, she has no vote. Conversely, Crawford has risen early to cast his ballot against the Labour leader whose commitment to modernisation, we infer, the Queen would also oppose if she could only - like so many of melodrama's mute characters - say so. Speaking on her behalf, Crawford protests that 'We're in danger of losing too much that's good about this country as it is.' Their exchange underlines the elderly artist's traditionalism as a portraitist in paint counterposed to the electronic images flickering in the background. It also establishes the limited powers of the constitutional monarch - deprived, she complains, 'of the sheer joy of being partial'. But if this deprivation, as well as the threat pronounced in the word 'moderniser', introduces the Queen as the victimised heroine traditional to melodrama (a victim who can confide in the traditionally victimised figure of the Caribbean immigrant) Mirren's performance of the role in full diva mode adds a contrasting note of humour. Reminded by Crawford that, although she cannot vote, it is her Government, she raises 
a regal eyebrow to observe drily, 'I suppose that is some consolation.' A cut to black enables Mirren's credit to punctuate this ethnic dialogue in contrasting white. Then, with Alexandre Desplat's theme tune swelling to its fanfare, the craning camera rises to conclude the scene - past the stately figure in the white brocade, the golden tassels, the midnight-blue mantle and the star-shaped emblem of the Order to fix on the face of the film's star in three-quarter profile. As she slowly turns toward the camera, her left eyebrow still aloft, another white title announces THE QUEEN, joining Mirren to her character in syntactical equivalence.

The celebrity culture of the nineteenth century is often credited with turning theatre stars into royalty, as the power of Europe's ruling families was increasingly curtailed and that of prominent entertainers increased. In the classical tragedies and historical dramas then performed, actors played monarchs, and offstage they socialised and sometimes coupled with them. The epitome of this phenomenon was Sarah Bernhardt, who consolidated her own stardom with the role of the victimised Spanish queen in Victor Hugo's romantic melodrama Ruy Blas and whose noble lovers are thought to include Elizabeth II's great-grandfather, who became Edward VII. One of The Queen's many ideological masterstrokes is its contemporary identification of the star actor (Mirren) with the world's most prominent living monarch as 'celebrities', in a highly reflexive narrative in which that term and its implications are explicitly discussed.

As with successor melodramas casting Colin Firth as George VI (in The King's Speech, 2010) and Meryl Streep as Margaret Thatcher (in The Iron Lady, 2011), Helen Mirren's casting as Elizabeth II identifies the political figurehead with a leading actor, rather than a lesser-known lookalike in the contemporary biopic tradition that casts Angela Bassett as Tina Turner or the young Cate Blanchett as Elizabeth I. Moreover, Mirren is an aristocrat among film stars, who has played classical queens like Cleopatra and Phèdre on the stage, whose supposed descent from the actual Russian aristocracy was remarked on the film's debut and who was dubbed a Dame of the British Empire soon afterwards. In 1994 she portrayed Queen Charlotte in The Madness of King George and in the 2005 HBO series, Elizabeth I, she joined a long line of star actresses, including Bernhardt, Bette Davis, Flora Robson, Glenda Jackson and Judi Dench, in portraying the first Queen Elizabeth. But Mirren's star persona has also retained the vein of rebellious sexiness embodied in her early stage roles as Shakespeare's Cressida (1968) and Strindberg's Miss Julie (1971), as well as an offscreen identification with progressive causes also manifest in her long-running police series Prime 
Suspect (1991-2006). Her rendition of its ageing, vulnerable and undoubtedly caring Detective Chief Inspector was clearly appropriated to make the monarch a sympathetic heroine, a female manager struggling to combine authority and virtue. ${ }^{15}$ The low-key grittiness of Mirren in that role also bolsters the televisual realism with which the docudrama elements of The Queen support its melodramatic fiction.

With but a few significant exceptions, the analysis of film melodrama now takes its historical cues from Peter Brooks' canonical study The Melodramatic Imagination. Brooks argues that the theatrical form originated in the aftermath of the revolutionary overthrow of political and religious authority, and by revolution he means the French revolution of $1789-95 .{ }^{16}$ But two key scenes in The Queen clearly refer to an earlier revolution, the English revolution that climaxed with the execution of Charles I in 1649. The emphatic 'Anglitude' of this film and its actors is ideological as well as historical, and it prompts a reconsideration of that other revolution and its relation to this dramatic mode. Here it is worth recalling that the intellectual developments signalled by the English revolution (religious scepticism, political contractarianism, scientific empiricism and an interest in what would now be called social psychology) included a sustained philosophical discussion of fame, variously articulated as 'honour', 'reputation' and 'esteem' by Thomas Hobbes, David Hume and Adam Smith.

Hobbes was an English royalist forced to flee the revolution to the Stuart stronghold in Paris. From exile in 1651, he published his political treatise Leviathan, in which he argues that a naturally quarrelsome humanity does so for three main motives - gain, safety and reputation. Although a monarchist, Hobbes was also an incipient materialist, and his analyses of both royal power and reputation are historically and analytically pertinent to The Queen. 'Reputation of power, is Power', ${ }^{17}$ Leviathan declares, in the apparent tautology which critics of the 'famous for being famous' formulae of contemporary celebrity culture wrongly imagine to be new. Honour in Hobbes's view derives not from personal worthiness but from public valuation, and it thus requires public acknowledgement: 'To be Conspicuous, that is to say, to be known, for Wealth, Office, great Actions, or any eminent Good, is Honourable. ... Obscurity, is Dishonourable. ${ }^{18}$ Similarly, in advocating the restoration of the English monarchy, Hobbes employs an extended theatrical metaphor to justify the sovereign's power. By his representative function, the monarch is said to 'personate' his subjects as the actor his role. In the interest of peace and prosperity, Leviathan urges the English to grant a new sovereign the 'Right to Present the Person of them 
all'. ${ }^{19}$ Here Hobbes exploits the ancient trope of the world-as-theatre invoked by his contemporary, the poet Andrew Marvell, who stages the execution of the theatre-loving Charles I as a play in his 'Horatian Ode', probably written in the year that Leviathan was published:

That thence the Royal Actor borne

The Tragick Scaffold might adorn:

While round the armed bands

Did clap their bloody hands. ${ }^{20}$

The stag scenes in The Queen are suffused with this memory of English history. They combine direct allusions to those events and their contemporary iconography with more recent references to the idealised representation of animals and the countryside painted by the Victorian Edwin Henry Landseer and animated by Disney. All of this rests on the ancient symbolism of the stag, from the horned god of the Celts to Christian representations of Jesus as a martyred deer to the animal's medieval association with the monarchs who monopolised its hunting by royal licence. The most obvious of these iconographic references is to the Roman goddess Diana, about whom Charles Spencer declared in his funeral eulogy to his sister, 'of all the ironies about Diana, perhaps the greatest was this - a girl given the name of the ancient goddess of hunting was, in the end, the most hunted person of the modern age'. Although the final words of Spencer's eulogy are included in one of the film's many insertions of television news footage, they do not include those just quoted. These cannot be spoken in the film, because its project is to secure the spectator's sympathy by substituting the Queen for Diana as the victim of the hunt.

This task is achieved by, first of all, tapping into the longtime association of the British monarchy with the natural world. As in its espousal of 'ancient' traditions and ceremonies (often devised in the nineteenth and twentieth centuries), this royal investment in the nation's 'rurality and imagined roots' identifies the Crown with what Tom Nairn calls a 'contrived timelessness', ${ }^{21}$ as manifested in the country pastimes of a folkloric public. (A similar invocation of the physical powers of sport ensures a royal attendance at every major competition.) Again, the modern version of this natural association was a Victorian creation, by the monarch herself in notable collaboration with Landseer, from whom she commissioned portraits of royal pets, royal gamekeepers, royal babies with their favourite pets and a life-size portrait of herself on horseback. Landseer often painted humans and animals in the Highlands, illustrated Walter Scott's 
Waverley novels, and most famously painted his widely reproduced study of a Highland stag, Monarch of the Glen, in 1851. The art direction of The Queen borrows shamelessly from these Victorian landscapes, toning the Balmoral costumes in their heather shades. Antlers hang from the walls and retrievers join the corgis on holiday from Buckingham Palace. Notably present is the cross-species identification that prompted Landseer to paint an entire series of dogs credited with rescuing people without human assistance and the French playwright François-René Guilbert de Pixérécourt to pen one of the greatest successes of early stage melodrama about another faithful hound, The Dog of Montargis.22

The Queen herself is emotionally rescued by a deer when she drives her Land Rover up to the moor where Prince Philip has taken her grandsons to escape their grief for their mother's death by stalking and killing animals. The irony of this inverted consolation begins when her vehicle breaks down fording a picturesque stream and she is forced to telephone her estate staff for help. As the troubled woman waits by the water the first stag scene opens, its intimate tone signalled by a medium close-up of her removing her headscarf, with its Gucci bridle design on white silk. Standing bareheaded in atmospheric birdsong, she turns away from the camera and begins to weep. An orchestration of harp and high strings fades in, with the majestic stag's sudden approach signalled by a poignant woodwind melody. On seeing it the melancholy monarch is transfixed, fervently exclaiming 'You beauty'. Then, at the sound of the approaching estate workers, she reciprocates the rescue, shooing the stag away to an equally magical disappearance synchronised to a Disney chime.

The second stag scene is announced when Philip informs the Queen that the one she saw has been killed by a 'commercial guest' on a neighbouring estate. Despite the increasing urgency of the week's events, she immediately drives there and is welcomed by the gamekeeper, who takes her to an octagonal stone outbuilding with a tiled floor and shuttered windows. Again birdsong yields to non-diegetic music, but now the woodwind theme is a wistful memory. In a descending shot that reverses the crane past the Queen in the opening scene, the hanging stag is revealed to be decapitated. Its large head, with its vast rack of antlers, rests on a sideboard. With his cap doffed, the gamekeeper identifies it as an 'imperial ... a fourteen-pointer'. The unusually long-lived specimen has been shot by a London banker who has failed to achieve a clean kill, subjecting the animal to lengthy suffering before its final dispatch. The now timely allusion to the investment banker who can't shoot straight, a vacation stalker 
out of touch with the organic community represented in the gamekeeper's evident familiarity with the Queen, recalls the supposed antagonism between the new rich and the nobility, one that was also inferred from the reported hostility displayed by Elizabeth Windsor toward Margaret Thatcher (the wife of an oil executive) during her premiership. (The Iron Lady's ostensible feminism rules out the representation of that intra-female conflict, attributing the aristocratic Tory opposition to Thatcher to male privilege.)

In the tradition of melodrama this second stag scene is one of recognition, the monarch drawing near to her impressively crowned counterpart to behold it in the kinship and foreboding telegraphed by the film's opening epigraph from Henry IV, Part II: 'Uneasy lies the head that wears the crown.' Her scarf in this scene is blood-red and replacing the hunter's bridle is a motif of gamebirds similar to those seen hanging behind the stag. These images of prey decorate the head of a queen whose reign has been exceptionally long and whose predecessor Charles I was deprived of his head by the victorious parliamentarians of the English revolution. (In the melodramatic muteness dramatised in The King's Speech, that of the moral man unable to speak, Charles I was also said to have overcome his stammer when denouncing his execution from the scaffold.) The stag hangs upside down like a deposed tyrant in a cooling room that resembles a mortuary - or the chapel in which the imprisoned Charles was pictured in the Guillaume Marshall portrait circulated by his supporters in a volume entitled Eikon Basilike: The Pourtraiture of his sacred maiestie in his solitarie suffering. With her mind concentrated wonderfully by the fate of one or both monarchs, and the gamekeeper's 'God bless you, Ma'am' ringing in her ears, another suffering monarch rapidly proceeds to propitiate her unhappy subjects, flying to London, communing with the mourners gathered at the gates of Buckingham Palace and - most importantly - broadcasting a tribute to the deceased princess.

In a film whose central issue is the power of mass media in public life, television screens are watched constantly, mostly by groups of people - kitchen staff, civil servants, the crowds in the park during Diana's funeral - following the news in figures of national attention. This vigilance commences in the title sequence with the Queen's viewing of the election report and continues with the announcement of Diana's crash, seen at Balmoral in the early hours of the morning by her, Prince Philip (James Cromwell), the Queen Mother (Sylvia Sims) and Prince Charles (Alex Jennings). Where a 1969 BBC documentary set a PR precedent by permitting the British public to witness the domestic life of the Royal Family, ${ }^{23}$ including a Highland barbecue gently parodied in The 
Queen, the film reverses the angle to make the Windsors the spectators. In their dressing-gowns and slippers, with the Queen clutching her hot-water bottle, the royal family could be the working-class Royle Family of British sitcom fame, ${ }^{24}$ passively gripped by public events, confused and irritable, unable to hear the telly over the conversation.

The Victorian social commentator Walter Bagehot observed that the notion of a 'family on the throne ... brings down the pride of sovereignty to the level of petty life'. ${ }^{25}$ Such is the scale of melodrama, Geoffrey Nowell-Smith writes, which typically 'supposes a world of equals ... exercising local power or suffering local powerlessness, within the family or the small town'. ${ }^{26}$ 'Familyness', Tom Nairn declares, is 'crucial for the sort of national-popular identity the Windsors purvey. ${ }^{27}$ Its varying generations and genders offer the public a contending cast of characters compared by Nairn in his 1989 study of the monarchy to that of the TV soap Dallas, while the inheritance of the throne through the bloodline represents both the organic continuity of the state and the retention of private property by the kin group. For this double function the virtue of the mother is crucial, and to best her rival the Queen must become a better one. Demonstrably cold to the son whose unhappy marriage she 'signed off on', she is distressed when he protests that Diana was loving to her children. Both they and the Queen's other offspring are never seen with the monarch. Instead, in this markedly matriarchal dynasty ${ }^{28}$ she seeks advice from her own elderly 'Mummy', who bracingly reminds her of the vow she took to the lifelong service of her country.

To retain her crown and become the good mother that the film requires, the Queen must establish a parental relation with her subjects, one that her Prime Minister is eager to enable. ${ }^{29}$ The Oedipality of Blair's filial devotion to the monarch is laughingly observed by his wife Cherie (Helen McCrory), portrayed in the film as a convinced republican, while his press secretary hails him as 'Mr Father of the Country'. And indeed the young Prime Minister and the older sovereign are the couple created by the film, united in their renewal of the British monarchy. But the Queen achieves a more conventional maternity when, returning at last to London, she halts her car at the gates of Buckingham Palace to order to inspect the tributes brought by Diana's mourners. As a startled reporter points out that such unscheduled encounters with the public are 'extremely unusual', Blair and his Downing Street staff watch its live broadcast on a bank of monitors. 'It really is', one TV commentator observes, 'as if the public and the royal family, the monarchy, have had a bit of a quarrel this 
week and now it is being healed.' 'Like a family spat', another helpfully explains. When Campbell interrupts with his revisions to 'the old bat's' eulogy of Diana, Blair rises in anger. Pointing to the screen, he shouts 'That woman has given her whole life in service to her people, fifty years doing a job she never wanted, a job she watched kill her father ... and now we're all baying for her blood.'

A cut to the Queen shows her pained perusal of a succession of commemorative messages in which Diana is portrayed as a religious martyr, her eyes uplifted and her head veiled, with captions declaring 'You were too good for them' and 'They have your blood on their hands.' The crowd is silent, with the clicking of cameras and the rustling of paper the only audible sounds. Turning away from the angry placards, the Queen asks a little girl behind the barricade if she would like her to place her bouquet. When the child declines, a close-up reveals Mirren's wounded expression, which is then transformed when the child explains 'These are for you.' As the relieved monarch carries her flowers past the mourners, the denunciations disappear and the women in the crowd silently begin to curtsey, one after another genuflecting to the Queen. In a sensation scene traceable to the pioneering melodramas of Pixérécourt, ${ }^{30}$ her own virtue is belatedly acknowledged, the public acknowledgement that Hobbes declared essential to honour.

The scene that follows is clearly designed to match the one which opens the film. Again the Queen is in dark clothing and again she looks directly into the camera, with the crowd visible in the window behind her. Her reprised stillness as she composes herself is that of the tableau traditional to melodrama, halting the action to seal the symbolic import of the scene. But her pose is not for a flattering depiction in oils but a live broadcast, and she is dressed in day wear and reading glasses, not the panoply of her Garter robes. Instead of a ceremonial portrait, the Queen is now the subject of a command performance over which she does not have, as she admits, 'a choice'. In reluctantly acceding to the popular demand for a televised tribute to Diana, not only does she take up the Princess's place in the pixelated frame, she also experiences the involuntary intimacy of a much less formal relation of regard, that of celebrity culture. She is, she proclaims, 'speaking as your Queen', but in Campbell's added phrase she continues, 'and as a grandmother', asserting her familial communality with the people she 'personates'.

Mass mediation is unsurprisingly associated with celebrity status in this film, and celebrity with Diana - the most prominent of global celebrities honoured at the film's end by the real-life Hollywood celebrities Tom Hanks, Steven 
Spielberg, Nicole Kidman and Tom Cruise in the footage of her funeral. Half a century after Muggeridge's warning, it is as though one member of the royal family had indeed become Rita Hayworth, or more grandly, the original 'Candle in the Wind', Marilyn Monroe. In a comic scene in The Queen, the c-word is actually spoken by her private secretary (Roger Allam) when he hesitantly reveals that Diana's funeral has had to be modelled on that planned for the Queen Mother, but with monarchs and heads of state replaced by 'a sprinkling of actors of stage and screen, fashion designers and other ... celebrities' - at which point Sylvia Sims's Queen Mother echoes 'celebrities' with an expression of incredulous distaste worthy of Edith Evans. But Sims is, of course, an actor of stage and screen. Notwithstanding her portrayal of royal disdain, the film is preoccupied by the same vulgar popularity that drives the narrative of its melodramatic ancestor, Mary Stuart.

In Schiller's 1800 play, the first Queen Elizabeth is forced to avert the claim to her throne posed by her cousin, Mary of Scotland, by imprisoning her. When her supporters' plotting continues, she reluctantly signs a warrant for Mary's execution. The speculation that Diana's death might have been similarly arranged is acknowledged in The Queen by Campbell's joking suggestion that Blair ask the Queen 'if she greased the brakes'. A further parallel between the play and the film is evident in a courtier's complaint that Mary's 'influence upon the human heart is too supreme'. ${ }^{31}$ After her love-struck supporter attempts to assassinate Elizabeth, the anti-Papist crowd calls for the Scottish queen's death. In a remarkable anticipation of the events portrayed in the film, Elizabeth is told 'it is thy people / who, round the palace ranged, impatient / demand to see their sovereign'. ${ }^{32}$ As her counsellors debate whether the public mood will turn again in favour of Mary, the beleaguered Queen asks:

when

Shall I once more be free upon this throne?

I must respect the people's voice, and strive

To win the favour of the multitude,

And please the fancies of a mob, whom naught

But jugglers' tricks delight. ${ }^{33}$

The fluctuation of the people's fancies was not only a pervasive dramatic theme in the post-revolutionary moment in which Schiller wrote Mary Stuart. It returns in a coda to The Queen which darkens the final exchange between the Prime Minister and his monarch when their weekly audiences at Buckingham Palace recommence in the autumn after Diana’s death. As Blair glibly attempts 
to reassure the sovereign that the republican rumblings of the summer have died away, she listens stonily and suddenly declares that the British public will one day turn against him - an anticipation of the dramatic loss of popularity which Blair had indeed experienced by the time of the film's production for his complicity in the invasion of Iraq. Like the final intertitle of The Deal, which notes that by its broadcast in 2003 Blair's promised handover of prime ministerial office to Gordon Brown had still not happened, this coda performs the ironic updating that often concludes the docudrama. But within this final sequence, the film stages a far more revealing acknowledgement of its own devices, an acknowledgement performed by denial.

Suggesting that they continue their discussion in the Palace gardens, the Queen leads Blair down a corridor. Suddenly she stops, removes her glasses and returns to the traumatic events of the summer. 'One in four?', she quietly asks, 'wanted to get rid of me?' Again Blair insists that this opposition was only momentary. 'I've never been hated like that before', the chastened monarch replies. Visible behind her is one of several marble statues in this scene. Presumably chosen to represent the neoclassical decor of Buckingham Palace, they lead to an extensive display of statuary in the formal garden in which the two are seen walking as the film's credits roll. Given the hitherto sustained opposition of painting and television, this sudden turn to the sculptural seems difficult to ignore.

As the Queen anxiously questions Blair she stands before a classical nude who looks modestly downward as she clasps a veil to her nether regions. But the naked intimacy suggested by this figure is soon dispelled as the Queen raises her voice and continues down the hallway: 'Nowadays', she declares, 'people want glamour and tears, the grand performance. I'm not very good at that.' At this point she passes a second statue, of an upright Victorian gentleman with his right hand tucked into his waistcoat and his left steadying a sheaf of papers. 'I prefer to keep my feelings to myself', she continues, 'and, foolishly, I believed that was what the people wanted from their queen - not to make a fuss, nor wear one's heart on one's sleeve. Duty first, self second.' As the Queen concludes her complaint, another classical statue briefly comes into view, of a sexually ambiguous figure whose short tunic is draped over a single shoulder.

If the woman averting exposure suggests Diana (the classical goddess furious to be seen bathing, the contemporary princess shielding her face from the paparazzi), does the frock-coated dignitary represent statesmanship and the third statue androgyny? Is this the film's final word on the dialectics of female 
rule? Or those of the phallic grandmother? Or does this marble, like the previous allusions to pixels and paint, refer to the varied media of dramatic personation? In the theatre of the eighteenth and early nineteenth centuries, the striking of 'attitudes' or dramatic poses based on those of classical sculpture was a familiar device. The English tragedienne Sarah Siddons and her French successor Rachel were both praised for the statuesque gravity of their posture and expression, while Henry James referred to the 'solidity' of Schiller's Mary when commending Helena Modjeska's 'exquisite and pathetic Queen of Scots' ${ }^{34}$ Mirren's own performances of stage tragedies readily link the film to this tradition.

If these statues invoke the 'classiness' of classicism, and the prestige sought from Mirren's casting, their cold whiteness may likewise suggest an era long before the modernising moment into which the film opens. Looking back to it the Queen defends her aversion to emotional display by saying 'that's how I was brought up'. But the catch in her voice as she recalls her coronation when 'just a girl' neatly subverts her protestation, signalling that her modesty about the grand performance is as false as that which veils the figure behind her. Rather than reading this scene as a final reversion to classical decorum and restraint, we should take it at face value, as still more evidence of the very emotional genre this leading lady has affirmed by her negation. For this is a film that truly does wear its melodramatic heart on its docudrama sleeve - its movie star monarch performing, pace Muggeridge, 'superlatively well whatever the public expects of her', the glamour and the tears that have brought us to an age of unparalleled royal celebrity.

\section{NOTES}

1 The Archers is a radio soap opera about rural British life broadcast on BBC Radio 4 since 1950. With the cancellation of the US Guiding Light in 2009, it has become the world's longest-running soap opera in any medium.

2 Malcolm Muggeridge, 'The royal soap opera' (first published in the New Statesman, 22 October 1955), republished by the New Statesman (30 May 2012), www.newstatesman.com/lifestyle/2012/05/back-royal-soap-opera.

3 Judith Williamson, 'Royalty and representation', in Consuming Passions: The Dynamics of Popular Culture (London and New York: Marion Boyars, 1986), p. 80.

4 Thomas Elsaesser, 'Tales of sound and fury: observations on the family melodrama', in Christine Gledhill (ed.), Home Is Where the Heart Is: Studies in Melodrama and the Woman's Film (London: BFI, 1987), p. 45.

5 William Shawcross, 'Portrait in majesty', Vanity Fair (June 2007), p. 106. 
6 David Thomson, 'Biographical dictionary of film number 99 (Stephen Frears)', Guardian (3 September 2010), p. 14.

7 See Graeme Turner, 'The cultural function of celebrity', in Understanding Celebrity (London: Sage, 2006), p. 96.

8 First broadcast in 1960, Coronation Street is a British television soap opera set in a fictional suburb of Manchester. In 1998, a character in it called Deidre Rachid was wrongfully imprisoned after a relationship with a con man. A national media campaign to free her ended the storyline with her 'release' three weeks later. In 2000, the Prince of Wales appeared on the show playing himself in a fictional news bulletin.

9 Allan Massie, 'Why Diana is still the spirit of the age', Telegraph (12 April 2008), www.telegraph.co.uk/news / uknews / 1584774/Why-Diana-is-still-the-spirit-ofthe-age.html.

10 Derek Paget, 'Making mischief: Peter Kosminsky, Stephen Frears and British television docudrama', Journal of British Cinema and Television 10:1 (2012), p. 188.

11 Belén Vidal, Heritage Film: Nation, Genre and Representation (London: Wallflower, 2012), p. 44.

12 Giselle Bastin, 'Filming the ineffable: biopics of the British royal family', Auto/ Biography Studies 24:1 (Summer 2009), p. 42.

13 Stephen Heath, Questions of Cinema (Bloomington: Indiana University Press, 1981), p. 21.

14 For a reading of this scene and its relation to other heritage films' use of portraiture, see Vidal, Heritage Film, pp. 42-3.

15 The public identification of Mirren with the role of Elizabeth II was arguably furthered by her toast to the monarch when accepting the 2007 Best Actress Oscar for the role: 'Ladies and gentlemen, I give you the Queen.' In 2013 and 2015, she again 'gave' theatre goers the Queen in Peter Morgan's The Audience, portraying the monarch's weekly private discussions with prime ministers ranging from Churchill to Cameron. Remarking on the play's 'two-hour exercise in propaganda for Elizabeth Windsor', Guardian journalist Jonathan Freedland observed, 'These days, in which our own favoured celebrities are those who have triumphed over adversity, it's not enough that we admire the monarch, we must feel sympathy too. ... Partly down to Mirren's ability to convey a sense of inner longings repressed, we believe this Queen when she sighs at "the unlived lives within us all".' Jonathan Freedland, 'After a night at the theatre with the Queen, I worry about democracy', Guardian (22 March 2013), www.theguardian.com/commentisfree/2013/mar/22/theatre-qu een-worry-democracy-politicians.

16 Peter Brooks, The Melodramatic Imagination (New Haven and London: Yale University Press, 1995), pp. 14-20.

17 Thomas Hobbes, Leviathan [1651], ed. Richard E. Flathman and David Johnston (New York and London: W. W. Norton, 1997), p. 48.

18 Ibid., p. 53.

19 Ibid., p. 96. 
20 Andrew Marvell, 'An Horatian Ode upon Cromwel's Return from Ireland', in Helen Gardner (ed.), The Metaphysical Poets (London: Penguin Books, 1961), p. 258.

21 Tom Nairn, The Enchanted Glass: Britain and Its Monarchy (London: Verso, updated 2nd edn, 2011), p. viii.

22 First staged in 1814, The Dog of Montargis was based on a fourteenth-century legend in which the faithful dog of a murdered knight finds the sash of the murderer and later keeps him from escaping.

23 Made by the BBC to publicise the Investiture of the Prince of Wales at Caernarvon in 1969, Royal Family was directed by Richard Cawston. Although its behind-the-scenes informality was controversial at the time, the programme's success prompted the Palace to ask Cawston to take over the production of the Queen's Christmas television broadcast from 1970 to 1985.

24 Produced by Granada Television for the BBC, The Royle Family is a situation comedy portraying a working-class family living in Manchester. It ran for three series between 1998 and 2000, with further special episodes in 2006, 2008, 2009 and 2010. The series reunited actors Ricky Tomlinson and Sue Johnston, the stars of the 1980s Channel 4 soap opera Brookside.

25 Walter Bagehot, The English Constitution [1867] (London: Fontana Library, 1963), p. 85.

26 Geoffrey Nowell-Smith, 'Minnelli and melodrama', in Gledhill (ed.), Home Is Where the Heart Is, p. 71.

27 Nairn, The Enchanted Glass, p. 37.

28 See David Cannadine, 'From biography to history: writing the modern British monarchy’, Historical Research 77:197 (2004), p. 303.

29 Confirming his own view of this maternal theme, director Stephen Frears has observed, 'Making a movie about the Queen is almost like making a movie about your mother and in England, the Queen really does serve as a kind of symbolic, emotional mother of the country.' Quoted in Emanuel Levy, 'The Queen according to Frears', Emanuel Levy: Cinema 24/7, www.emanuellevy.com/interview/ the-queen-according-to-frears.

30 In The Melodramatic Imagination (p. 27), Brooks argues that melodrama 'is about virtue made visible and acknowledged, the drama of recognition'. His example is Pixérécourt's 1819 La Fille de l'exilé, in which a band of fierce Tartars fall to their knees before a young woman who has heroically forgiven the persecutor of her father.

31 Friedrich Schiller, Mary Stuart: A Tragedy, trans. Joseph Mellish, Project Gutenberg ebook, last updated November 2012, Act I, Scene 8 (no pagination), www.gutenberg.org/files / 6791/6791-h/6791-h.htm.

32 Ibid., Act IV, Scene 7.

33 Ibid., Scene 10.

34 Henry James, 'The London theatres' [1880], in Allan Wade (ed.), The Scenic Art: Notes on Acting and Drama (London: Rupert Hart-Davis, 1949), p. 161. 
Bastin, Giselle, 'Filming the ineffable: biopics of the British royal family', Auto/ Biography Studies 24:1 (2009).

Bagehot, Walter, The English Constitution [1867] (London: Fontana Library, 1963).

Brooks, Peter, The Melodramatic Imagination (New Haven: Yale University Press, 1995).

Cannadine, David, 'From biography to history: writing the modern British monarchy', Historical Research 77:197 (2004).

Elsaesser, Thomas, 'Tales of sound and fury: observations on the family melodrama', in Christine Gledhill (ed.), Home Is Where the Heart Is: Studies in Melodrama and the Woman's Film (London: BFI, 1987).

Freedland, Jonathan, 'After a night at the theatre with the Queen, I worry about democracy', Guardian (22 March 2013), www.theguardian.com/ commentisfree $/ 2013 / \mathrm{mar} / 22 /$ theatre-queen-worry-democracy-politicians.

Heath, Stephen, Questions of Cinema (Bloomington: Indiana University Press, 1981).

Hobbes, Thomas, Leviathan [1651], ed. Richard E. Flathman and David Johnston (New York and London: W. W. Norton, 1997).

James, Henry, 'The London theatres' [1880], in Allan Wade (ed.), The Scenic Art: Notes on Acting and Drama (London: Rupert Hart-Davis, 1949).

Levy, Emanuel, 'The Queen according to Frears', Emanuel Levy: Cinema 24/7, www.emanuellevy.com/interview/the-queen-according-to-frears.

Marvell, Andrew, 'An Horatian Ode upon Cromwel's Return from Ireland', in Helen Gardner (ed.), The Metaphysical Poets (London: Penguin Books, 1961).

Massie, Allan, 'Why Diana is still the spirit of the age', Telegraph (12 April 2008), www.telegraph.co.uk/news/uknews/1584774/ Why-Diana-is-still-thespirit-of-the-age.

Muggeridge, Malcolm, 'The royal soap opera' (first published in the New Statesman, 22 October 1955), republished by the New Statesman (30 May 2012), www.newstatesman.com/lifestyle/2012/05/back-royal-soap-opera.

Nairn, Tom, The Enchanted Glass: Britain and Its Monarchy (London: Verso, updated 2nd edn, 2011).

Nowell-Smith, Geoffrey, 'Minnelli and melodrama', in Christine Gledhill (ed.), Home Is Where the Heart Is: Studies in Melodrama and the Woman's Film (London: BFI, 1987).

Paget, Derek, 'Making mischief: Peter Kosminsky, Stephen Frears and British television docudrama', Journal of British Cinema and Television 10:1 (2012).

Schiller, Friedrich, Mary Stuart: A Tragedy, trans. Joseph Mellish, Project Gutenberg ebook, last updated November 2012, www.gutenberg.org/ files / 6791/ 6791-h/ 6791-h.htm.

Shawcross, William, 'Portrait in majesty', Vanity Fair (June 2007). 
Thomson, David, 'Biographical dictionary of film number 99 (Stephen Frears)', Guardian (3 September 2010), p. 14.

Turner, Graeme, 'The cultural function of celebrity', in Understanding Celebrity (London: Sage, 2006).

Vidal, Belén, Heritage Film: Nation, Genre and Representation (London: Wallflower, 2012).

Williamson, Judith, 'Royalty and representation', in Consuming Passions: The Dynamics of Popular Culture (London: Marion Boyars, 1986). 